\title{
SOKAK AYDINLATMALARINDA KULLANILACAK YÜKSEK GÜÇLÜ LED'LERİN TERMAL PERFORMANSININ SAYISAL VE DENEYSEL OLARAK İNCELENMESI
}

\author{
Burcu ÇiÇEK*, Necmettin ŞAHİN
}

Aksaray Üniversitesi Mühendislik Fakültesi, Makine Mühendisliği Bölümü, Aksaray, Türkiye.

\begin{tabular}{ll}
\hline Anahtar Kelimeler & Öz \\
\hline LED, & Bu çalışmada, sokak aydınlatmalarında kullanılan yüksek güçlü LED'lerin \\
ISı Borusu, & soğutulması için ısı borulu soğutucu tasarımı yapılmıştır. Dört adet yüksek güçlü \\
ANSYS, & LED, dörtgensel alüminyum plaka üzerine yerleştirilmiş ve U şeklinde üç adet \\
Türbülans Modeli. & silindirik bakır ısı borusu, alüminyum plakanın içinden geçecek şekilde monte \\
& edilmiştir. Isı borusunun ısıyı doğal taşınım ile dış ortama aktarabilmesi için, ısı \\
& borusunun yoğuşturucu bölgesine kanatçıklı sogutucu plaka yerleştirilmiştir. \\
& Tasarlanan sistemin termal analizi, nümerik olarak ANSYS Fluent yazılımında \\
& yapılmıştır. Analizlerde sırasıyla, 15 W, 20 W ve 25 W'lık elektriksel giriş güçlerinin \\
& sistem sıcaklık dağılımına etkisi incelenmiştir. Buna ek olarak, sayısal analizlerde, \\
& çözüm metodu olarak farklı türbülans modeli ve duvar yaklaşımlarının sıcaklık \\
dağllımına etkisi de incelenmiştir. Sayısal çözümlerin doğrulanması için deneysel & çalışma yapılmıştır. Sayısal ve deneysel sonuçlar birbiriyle uyumlu olduğu \\
& gözlenmiştir.
\end{tabular}

\section{NUMERICAL AND EXPERIMENTAL ANALYSIS OF THE THERMAL PERFORMANCE OF HIGH} POWER LEDS TO BE USED FOR STREET LIGTHING

\begin{tabular}{ll}
\hline Keywords & Abstract \\
\hline LED, & In this study, heat pipe - heat sink geometry was designed for cooling high power \\
Heat Pipe, & LEDs used in street lighting. Four high-power LEDs were placed on a rectangular \\
ANSY, & aluminum plate and three U-shaped cylindrical copper heat pipes were mounted so \\
Turbulence Model. & that they will pass through aluminum plate. In order to transfer heat from heat pipe \\
& to the ambient by natural convection, a heat sink with fins was placed in the heat \\
pipe condenser zone. Thermal analysis of the designed system was carried out & numerically in ANSYS Fluent software. Analysis were performed for $15 \mathrm{~W}, 20 \mathrm{~W}$ and \\
& 25 W of electrical input power, respectively. In addition, the effects of different \\
& turbulence models and wall approaches on temperature distribution were also \\
& investigated. Experimental study was performed to verify numerical solutions. \\
& Numerical and experimental results were observed to be consistent.
\end{tabular}

Alıntı / Cite

Cicek, B., Sahin, N., (2020). Sokak Aydınlatmalarında Kullanılacak Yüksek Güçlü LED'lerin Termal Performansının Sayısal ve Deneysel Olarak İncelenmesi, Mühendislik ve Tasarım Bilimleri Dergisi, 8(1), 185-197 \begin{tabular}{l|l}
\hline Yazar Kimliği / Author ID (ORCID Number) & Makale Süreci / Article Process
\end{tabular}

B. Çiçek, 0000-0002-1777-4980

N. Şahin, 0000-0002-5756-4216

Başvuru Tarihi / Submission Date

Revizyon Tarihi / Revision Date

Kabul Tarihi / Accepted Date

Yayım Tarihi / Published Date

\section{Giriş (Introduction)}

Gelișen teknoloji ile birlikte, ıșık yayan diyotlar (LED), enerji tasarrufu, yüksek ışık akısı, güvenirlik ve uzun ömür gibi avantajlarından dolayı genel aydınlatmalarda tercih edilmektedir (Pimputkar vd., 2009). Bütün bu avantajlara rağmen, LED’ler, üzerine uygulanan elektriksel gücün sadece \%20-25'lik kısmını ışık enerjisine dönüştürürken, geriye kalan kısmını ısı enerjisine dönüştürmektedir. LED’lerde yüksek sıcaklığa neden olan bu durum, LED'in ışık

\footnotetext{
*ilgili yazar / Corresponding author: cicekb@aksaray.edu.tr, +90-382-288-3691
} 
çıkışı, ışık rengi ve ömrünü olumsuz etkilemektedir. Özellikle yüksek güçlü LED'lerde, jonksiyon sıcaklığı, izin verilen sınırın altında tutulmalıdır. Bu nedenle, LED'in etkin termal yönetimi, LED performansını artırmak için kritik öneme sahiptir.

Bu çalışmada, sokak aydınlatmalarında kullanılan yüksek güçlü LED’lerin soğutulması için soğutucu model tasarımı yapılmıştır. Tasarımda, U șeklinde bakır ısı boruları alüminyum soğutucu plakaya entegre edilmiștir. Geliştirilen soğutucu model üzerinde yüksek güçlü dört adet eş COP LED kullanılmıştır. Tasarlanan sistem sayısal olarak $15 \mathrm{~W}, 20 \mathrm{~W}$ ve $25 \mathrm{~W}$ elektriksel giriş gücü için analiz edilmiştir. Sayısal model farklı türbülans modeli ve duvar yaklaşımlarında tekrar edilmiştir. Analizler sonunda, sistemin belirli noktalardaki sıcaklık değeri alınıp, jonksiyon sıcaklıkları elde edilmiştir. Sayısal sonuçların doğrulanması için deneysel çalışma yapılmıştır. Buna göre geliştirilen model için uygun türbülans modeli ve duvar yaklaşımı belirlenmiştir.

\section{Kaynak Araștırması (Literature Survey)}

Literatürde LED’lerin soğutulmasına yönelik birçok çalışma mevcuttur. Isıl iletkenliği yüksek, herhangi bir ek bir parça ve bakım gerektirmeyen ve dolayısıyla maliyeti düşük olan ısı boruları, LED’lerin soğutulması için uygun bir yöntem olarak görülmektedir. Elnaggar vd. (2011) PC-CPU soğutması için U şeklinde ısı borusu kullanmışlardır. Isı borusuna kanatçıklı soğutucu plaka monte edilmiştir. Sistem, dikdörtgensel bir tünel içersinde yer alan bir ısı kaynağı üzerine dikey olarak monte edilmiştir.Toplam termal direnç ve ısı transfer katsayısının belirlenmesi için hem sayısal hem de deneysel çalışma yürütülmüştür. Tang vd. (2014) yüksek güçlü LED'li aydınlatma için kurşun çerçeveli sütun ısı borusu (CHP) geliştirmişlerdir. Kurşun çerçeveli ısı borusu, radyal alüminyum soğutucu plakaya monte edilmiştir. Isı borulu LED'li aydınlatmanın termal performansı, parlaklığı ve kromatikliği deneysel olarak incelenmiștir. Sonuç olarak, yüksek güçlü LED'li aydınlatmalarda, kurşun çerçeveli sütun ısı borusunun iyi bir performans sergilediği görülmüştür. Cai vd. (2017) çoklu ısı kaynağı olan elektroniklerin ısı dağılımını sağlamak için, çok dallı bir ısı borusu geliştirmiş̧lerdir. Geliştirilen ısı borusu, iki buharlaştırıcı ve bir yoğuşturucudan oluşan, buhar ve sıvı hatları ile birbirine bağlantılı üç kola sahiptir. Isı borusunun doluluk oranı, başlangıç özellikleri, güç dağılım grafiği ve termal direncini incelemek için testler uygulanmıştır.

Moon vd. (2016) tarafından yüksek güçlü LED'li aydınlatma için ısı borusu geliştirmiştir. Isı borusunun etrafına U şeklinde düz alüminyum kanatçıklar yerleștirilmiştir. 100 W'lık tekli LED, oluşturulan soğutucunun üstüne monte edilmiştir. Tasarlanan ısı borulu sistem, alüminyum kanatçıkların farklı boyutları için modellenerek, simüle edilmiştir. Simülasyon sonucu optimum boyutlar belirlenmiştir. Wang vd. (2017) yüksek güçlü LED'leri soğutmak için soğutucu plaka olarak alüminyumdan yapılmış radyatör modeli kullanmışlardır. Radyatör modelinde, bir mandrel etrafına radyal tipi düz kanatçıklar eklenmiştir. Daha sonra mandrel kısmına bir ısı borusu monte ederek elde edilen modelin termal davranışını nümerik çalışma ile incelemiş̧lerdir. Sonrasında nümerik çalışmadan elde edilen verilerin doğrulanması için deneysel testler yapılmıştır. Sonuçlar, radyatör yüksekliği, kanatçık sayısı ve yüksekliği artırıldığında, LED jonksiyon sıcaklığının düştüğünü ve kanatçık kalınlığının, Nu sayısı üzerindeki etkisinin \% 1'den az olduğunu göstermiştir.

Schmid vd. (2017) 150 W'lık LED sokak aydınlatmaları için, aktif bir hava soğutma sisteminin parçası olarak, çift borulu bir ısı değiştiricisini deneysel ve sayısal olarak incelemişlerdir. Sayısal olarak, iki boyutlu, simetrik eksenli bir model oluşturulup, boru uzunluğu, malzeme iletkenliği, akış yönü, boru çap oranı, kütle akış hızı ve ısı aktarım hızı gibi değișen parametrelerin sistemin termal davranışına etkisi incelenmiştir. Sayısal çalışmadan alınan veriler, deneysel verilerle uyumlu çıkmıştır.

LED'lerin soğutulması için tasalanan ısı borulu sistemlerin termal analizleri deneysel çalışmaların yanı sıra sayısal analizler de yapılmıștır. Suresh ve Bhramara (2016) iki fazlı bir ısı değiştirici olan titreşimli ısı borusu (PHP) tasarlamıştır. Tasarlanan isı borusu, ANSYS CFX'de modellenip simüle edilmiștir.Buharlaștırıcıdaki aseton sıcaklığındaki düşüş, ısının kondenser bölgesine taşındığını göstermiştir. Isı borusunu oluşturan evaporatör, kondenser ve adyabatik bölgelerindeki hava ve aseton hacimsel oranının PHP içindeki akış modeline yansıdığı görülmüștür.

Asmaie vd. (2013) iki fazlı akış ile ısı transferi sağlayan termosifonun simülasyonu için hesaplamalı akışkanlar dinamiği (CFD) modeli geliştirmiştir. Çalışma akışkanı olarak damıtılmış su ve CuO/su nanoakışkanı kullanılmıştır. Sonuçlar, nanoakışkandaki ısı transferinin, suya göre yaklaşık \% 46 daha yüksek olduğunu göstermiştir. Bununla birlikte nanoakışkan konsantrasyonu artırılarak duvar sıcaklığının azaldığı ve optimum konsantrasyon değerinin ağırlıkça \% 1 olduğu görülmüştür.

Ashish vd. (2016) ısı borusunun termal davranışını farklı işletme koşullarında deneysel ve sayısal olarak incelemiştir.Tasarlanan modelin simülasyonu ANSYS Fluent yazılımında yapılmıştır. Sayısal ve deneysel sonuçlar birbiriyle uyumlu çıkmıştır. Isı borusu damıtılmış su ve $40 \mathrm{~nm}$ ve $70 \mathrm{~nm}$ çapındaki $\mathrm{CuO}+\mathrm{BN}$ hibrit 
nanoparçacıkları ile yüklenmiştir. Sonrasında güç girişleri, ısı borusu eğim açısı ve nanopartikül konsantrasyonunun ısı borusunun termal direncine etkileri araştırılmıştır. Sonuçlar, \% 2'lik hacimsel konsantrasyondaki $\mathrm{CuO}$ + BN / H2O hibrit nanoakışkanların maksimum ısı transferi sağlamak için etkili olduğunu göstermiştir.

Lin vd. (2013)minyatür salınımlı ısı borularının (MOPH) ısı transfer mekanizmalarını incelemek ve ıSı transfer kapasitelerini tahmin etmek amacıyla fiziksel ve matematiksel model oluşturmuştur. Simülasyonlar ANSYS Fluent yazılımında yapılmıştır. Çözüm modeli olarak Volume of Fluid (VOF) ve Mixture Model kullanılmış ve iki model karşılaştırılmıştır. Sonuçlar MOPH'da, mixture modelinin iki fazlı akış simülasyonları için daha uygun olduğunu göstermiștir.

Naveenkumar vd. (2015) tarafından yapılan çalışmada, farklı fitil kalınlıkları ve yapılarında ıSı boruları tasarlamıștır. Tasarlanan bu ısı boruları, ANSYS CFX programında modellenerek simüle edilmiştir. Isı borusu malzemesi olarak silika, fitil malzemesi olarak nikel alaşımı ve çalışma akışkanı olarak da su, metanol ve sıvı metanol kullanılmıştır. Her bir fitil yapısı, kalınlığı ve çalışma akışkanı için sıcaklık gradyanı ve ısı transfer katsayıları elde edilmiştir.

Dev ve Budania (2016) ısı borusunun kararlı hal performanslarını analiz etmek için iki boyutlu sonlu elemanlar metodunu geliştirmiştir. Geliştirdikleri modeli ANSYS Fluent yazılımında kullanmışlardır. Çalışmada, ısı borusu duvar malzemesi, fitil efektif ısıl iletkenliği, ısı borusuna giren ısı akısı ve çalışma akışkanları gibi parametreleri değiștirilerek ısı borusu boyunca sıcaklık dağılımı belirlenmiştir.

Huang Vd. (2019) soğutucu plaka üzerindeki yivli bir ısı borusuna kanatçıklı yapı dahil ederek LED'in ıSı transfer verimliliğini artırmaya çalışmışlardır. LED yoncası sıcaklığını güvenli bir çalışma aralığında koruyabilmek için ANSYS Fluent yazılımında ısı borusu parametreleri ve kanatçıklı yapı optimize edilmiştir. Çalışma sonucunda yüksek termal verimliliğin yeterli olmamasına rağmen LED jonksiyon sıcaklı̆̆ında düşüş görülmüștür.

\section{Materyal ve Yöntem (Material and Method)}

Yeni nesil yüksek güçlü LED’ler, oldukça kompakt boyutlara sahiptir. Bu durum, onlara kullanışlılık sağlamakla birlikte, birim hacim bașına yüksek bir ısı akısı oluşması sorununu da beraberinde getirmektedir. Bu yüksek ısı akısı, LED’lerdeki jonksiyon sıcaklığında artışa neden olmaktadır. Oluşan yüksek sıcaklıklar, LED'lere zarar vererek faydalı ömürlerini kısaltmaktadır.Bu nedenle, LED’lerden ısıyı uzaklaştırarak, LED jonksiyon sıcaklığını izin verilen en büyük değerin altında tutmak önemlidir. Pratik kullanıma hazır her LED armatüründe, bu amaca yönelik bileşenler bulunmak zorundadır. Bu çalışmada, sokak aydınlatmalarında kullanılan yüksek güçlü LED'lerin soğutulması için, ısı borulu soğutucu tasarlanmıştır. LED’lerde oluşan ısı akısı, ilk olarak, üzerine monte edildiği alüminyum soğutucu plaka yardımıyla, yüksek ısıl iletkenliğe sahip olan ısı borusuna aktarılır. Isı, buradan, çalışma akışkanının faz değişimi sonucu çekilerek, ısı borusu kondenser bölgesi üzerine yerleștirilen kanatçıklı soğutucu plakalara ve buradan da doğal taşınım yoluyla dış ortama geçiş yapar.

Tasarlanan sistem, sayısal olarak ANSYS Fluent yazılımında modellenmiș ve simüle edilmiștir.Simülasyon sonuçlarını deneysel olarak doğrulamak için sistemin bir prototipi üretilmiștir. Deneysel çalışmada, LED’lere güç kaynağı yardımıyla enerji beslemesi sağlanmıştır. Sistem ısıl dengeye geldikten sonra, hem K-tipi termokupllar hem de termal kamera ile sistemin farklı noktalarından sıcaklık ölçümleri alınmıştır. Deneysel çalışmanın amacı, sayısal modelde elde edilen değerlerin, gerçek değerlere hangi oranlarda yaklaştığını görmektir.

\subsection{Sayısal Modelleme (Mathematical Model)}

Isı borusu içindeki ısı transferi ve akışkan akışı çok karmaşık bir süreçtir. Buna bağlı olarak hesaplamalı akışkanlar dinamiğinde termal simülasyon bir çok faktöre bağlıdır. Geometrik modelin oluşturulması, fiziksel alana entegrasyonu, ağ yapısını oluşturma ve uygun bir sayısal hesaplama düzeni seçimi, simülasyon sürecinin başarı düzeyini belirleyebilen önemli faktörlerdir. Bu çalışmada tasarlanan sistemin termal analizi sayısal olarak Ansys 15.0 Fluent yazılımında yapılmış ve üç aşamada çözülmüştür.

Ön ișlemcide, LED’lerin ısı borulu soğutucu plakaya entegre edilmesiyle tamamlanan sistem, Ansys Workbench'te modellenmiștir. Sistemin geometrisi Şekil 1'de verilmiştir. Tasarlanan sistemde kullanılan dört adet 25 W'lık LED'lerin soğutulması için U-tipi silindirik bir ısı borusu kullanılmıştır. Isı borusu,üç adet bileşenden oluşmaktadır. Bunlar evaporatör, adyabatik ve kondenser bölgeleridir. Evaporatör bölgesi, ısıyı alıp kondenser bölgesine iletmek için kurulan bir mekanizmadır ve bu nedenle ısı üretiminin maksimum olduğu LED'in hemen altındaki alüminyum plakaya yerleştirilmiştir. Sistemden doğal taşınımla maksimum miktarda ısı atılabilmesi için, ısı borusu kondenser bölgesine kanatçıklı alüminyum soğutucu plaka entegre edilmiştir. 


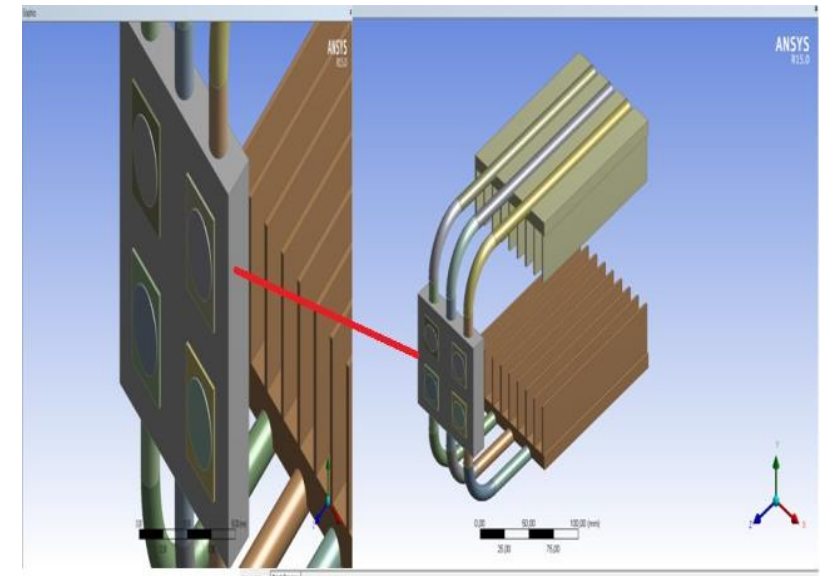

Şekil 1. Tasarlanan Modelin Geometrisi (Geometry of The Designed Model)

LED'lerinin soğutulması için tasarlanan soğutucu plaka ve kanatçıkların özellikleri Tablo 1 'de, U-tipi silindirik ısı borusunun özellikleri ise Tablo 2'de verilmiştir.

Tablo 1. Soğutucu Plaka ve Kanatçık Özellikleri (Properites of Heat Sink and Fins)

\begin{tabular}{|l|l|}
\hline Parametre & Değer \\
\hline Soğutucu plaka uzunluğu & $0.150 \mathrm{~m}$ \\
\hline Kanatçık genişliği & $0.100 \mathrm{~m}$ \\
\hline $\begin{array}{l}\text { İki kanatçık arasındaki } \\
\text { mesafe }\end{array}$ & $0.012 \mathrm{~m}$ \\
\hline Kanatçık yüksekliği & $0.035 \mathrm{~m}$ \\
\hline Kanatçık kalınlığı & $0.001 \mathrm{~m}$ \\
\hline Kanatçık sayısı & 9 \\
\hline
\end{tabular}

Tablo 2. Isı Borusunun Özellikleri (Properties of Heat Pipe)

\begin{tabular}{|l|l|}
\hline Parametre & Değer \\
\hline $\begin{array}{l}\text { Toplam ısı borusu } \\
\text { uzunluğu }\end{array}$ & $0.58 \mathrm{~m}$ \\
\hline $\begin{array}{l}\text { Isı borusu kondenser } \\
\text { uzunluğu }\end{array}$ & $0.20 \mathrm{~m}$ \\
\hline $\begin{array}{l}\text { Isı borusu evaporatör } \\
\text { uzunluğu }\end{array}$ & $0.10 \mathrm{~m}$ \\
\hline Isı borusu çapı (D) & $0.010 \mathrm{~m}$ \\
\hline Isı borusu malzemesi & Bakır \\
\hline Toplam ısı girişi & $100 \mathrm{~W}$ \\
\hline $\begin{array}{l}\text { Isı borusu ısı iletim } \\
\text { katsayısı }\end{array}$ & 10000 \\
\hline Çalışma akışkanı & $\mathrm{W} / \mathrm{m} . \mathrm{K}$ \\
\hline
\end{tabular}

Geometri modellendikten sonra, sonlu elemanlar ağ yapısı olușturulmuștur. Sonlu elemanlar ağ yapısı oluşturulurken, üçgen elemanlardan oluşan bir ağ yapısı oluşturulmasına dikkat edilmiştir.Tasarlanan sistemde, iç içe iki akışkan alanı oluşturulmuştur. İçte oluşan akış alanında daha sık bir ağ yapısı oluşturulurken dıştaki akış alanında ağ yapısı daha seyrek oluşturulmuştur. Ağ yapısı oluşturma işlemi sonunda, model üzerinde 5643861 eleman ve 1305380 düğüm noktası meydana gelmiştir. Ağ yapısı oluşturulurken minimum eleman boyutu 0.20 mm olarak seçilmiș ve Skewness faktörünün 0.96'nın altında olması sağlanmıștır. Oluşturulan ağ yapısının detaylı resimleri Şekil 2 de gösterilmiştir. 


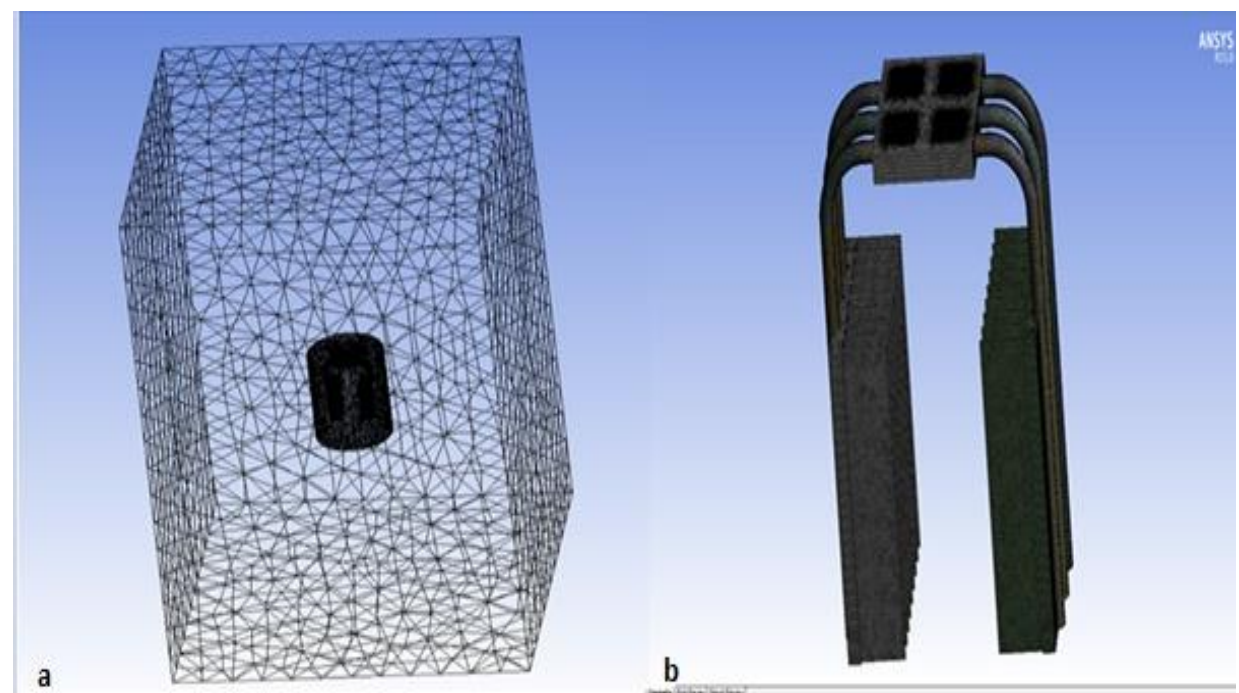

Şekil 2. Tasarlanan Sistemin a. Akış Alanı İle Birlikte, b. Akış Alanı Hariç Ă̆ Yapısı (Mesh Structure of Designed System a. With Flow Area b. Without Flow Area)

Çözümde Couple çözüm metodu, akış modeli olarak da Turbulent Mixing Length modeli kullanılmıștır. Modeli tanımlarken enerji denklemleri açık tutulmuş ve hesaplamalı akışkanlar dinamiği problemlerinde kullanılan üç adet denklem kullanılmıştır. Bunlar süreklilik, momentum ve enerji denklemleridir. Bu üç denkleme genel olarak Navier-Stokes denklemleri adı verilir. Akıştaki çoğu akışkanın genel olarak matematiksel olarak çözümü son iki denklemde gerçekleşir. Bu üç denklem sırasıyla Eşitlik (1-5)'de gösterilmiştir.

$\underline{\text { Süreklilik denklemi }}$

$$
\frac{\partial u}{\partial x}+\frac{\partial v}{\partial y}+\frac{\partial w}{\partial z}=0
$$

Momentum denklemi

$\underline{x-y o ̈ n u ̈ ~}$

$$
\rho\left(u \frac{\partial u}{\partial x}+v \frac{\partial u}{\partial y}+w \frac{\partial u}{\partial z}\right)=-\frac{\partial \rho}{\partial x}+\mu\left(\frac{\partial^{2} u}{\partial x^{2}}+\frac{\partial^{2} u}{\partial y^{2}}+\frac{\partial^{2} u}{\partial z^{2}}\right)
$$

y-yönü

z-yönü

$$
\rho\left(u \frac{\partial v}{\partial x}+v \frac{\partial v}{\partial y}+w \frac{\partial v}{\partial z}\right)=-\frac{\partial \rho}{\partial y}+\mu\left(\frac{\partial^{2} v}{\partial x^{2}}+\frac{\partial^{2} v}{\partial y^{2}}+\frac{\partial^{2} v}{\partial z^{2}}\right)
$$

Enerji denklemi

$$
\rho\left(\mathrm{u} \frac{\partial \mathrm{w}}{\partial \mathrm{x}}+\mathrm{v} \frac{\partial \mathrm{w}}{\partial \mathrm{y}}+\mathrm{w} \frac{\partial \mathrm{w}}{\partial \mathrm{z}}\right)=-\frac{\partial \rho}{\partial \mathrm{z}}+\mu\left(\frac{\partial^{2} \mathrm{w}}{\partial \mathrm{x}^{2}}+\frac{\partial^{2} \mathrm{w}}{\partial \mathrm{y}^{2}}+\frac{\partial^{2} \mathrm{w}}{\partial \mathrm{z}^{2}}\right)
$$

$$
\left(\mathrm{u} \frac{\partial \mathrm{T}}{\partial \mathrm{x}}+\mathrm{v} \frac{\partial \mathrm{T}}{\partial \mathrm{y}}+\mathrm{w} \frac{\partial \mathrm{T}}{\partial \mathrm{z}}\right)=\frac{1}{\alpha}+\mu\left(\frac{\partial^{2} \mathrm{w}}{\partial \mathrm{x}^{2}}+\frac{\partial^{2} \mathrm{w}}{\partial \mathrm{y}^{2}}+\frac{\partial^{2} \mathrm{w}}{\partial \mathrm{z}^{2}}\right)
$$

\subsection{Deneysel Çalışma (Experimental Study)}

Deneysel çalışma için, iç ve dış çapları sırasıyla $0.3 \mathrm{~mm}$ ve $10 \mathrm{~mm}$ olan U şeklinde üç adet bakır ısı borusu imal edilmiştir. Isı borularının evaporatör bölgeleri, 80 x 80 mm'lik bir soğutucu plakanın içinden geçecek şekilde monte edilmiștir. Sonrasında, LED'ler, olușan ısının iletilmesi için, bu soğutucu plakanın üzerine yerleștirilmiștir. Isı borularının kondenser bölgelerine alüminyum soğutucu plakalar monte edilmiştir. Bu soğutucu plakaların üzerine, ısı transfer yüzey alanını artırmak için, kanatçıklı yapılar yerleştirilmiştir. Kanatçıklı yapıların profili dikdörtgen şeklinde olup, $35 \mathrm{~mm}$ kalınlığında ve $2 \mathrm{~mm}$ genişliğindedir. Isı borularının içinde, kapiler etkiyi ve ısıl iletkenliği sağlaması için Sinterlenmiş Metal Fitil yapısı kullanılmıştır. Sinterlenmiş Metal Fitil yapısı, metal partiküllerinin kalıplarda preslenerek şekillendirilmesi ve fırınlarda sinterlenmesi ile oluşturulmaktadır. Isı borularında, dış duvar malzemesi olarak, ısı iletim katsayısı oldukça yüksek olan bakır, çalışma akışkanı olarak da saf su kullanılmıştır. 
Bu çalışmada, ısı borulu soğutucu plakaya monte edilmek üzere, 25 W'lık dört adet Lumileds Luxeon 1208 model COB LED kullanılmıştır. COB LED'lere enerji beslenebilmesi için LED'lere lehim yoluyla bağlantı yapılmıştır. Lehim yaparken lehim sıcaklığının $300^{\circ} \mathrm{C}$ yi geçmemesine ve enerji beslemesi yapılırken (kablolardan yüksek oranda akım geçeceğinden) çok ince kablolarla bağlantı yapılmamasına dikkat edilmiştir. LED'leri çalıştırmak için paralel bağlama yapılmıștır (Şekil 3).

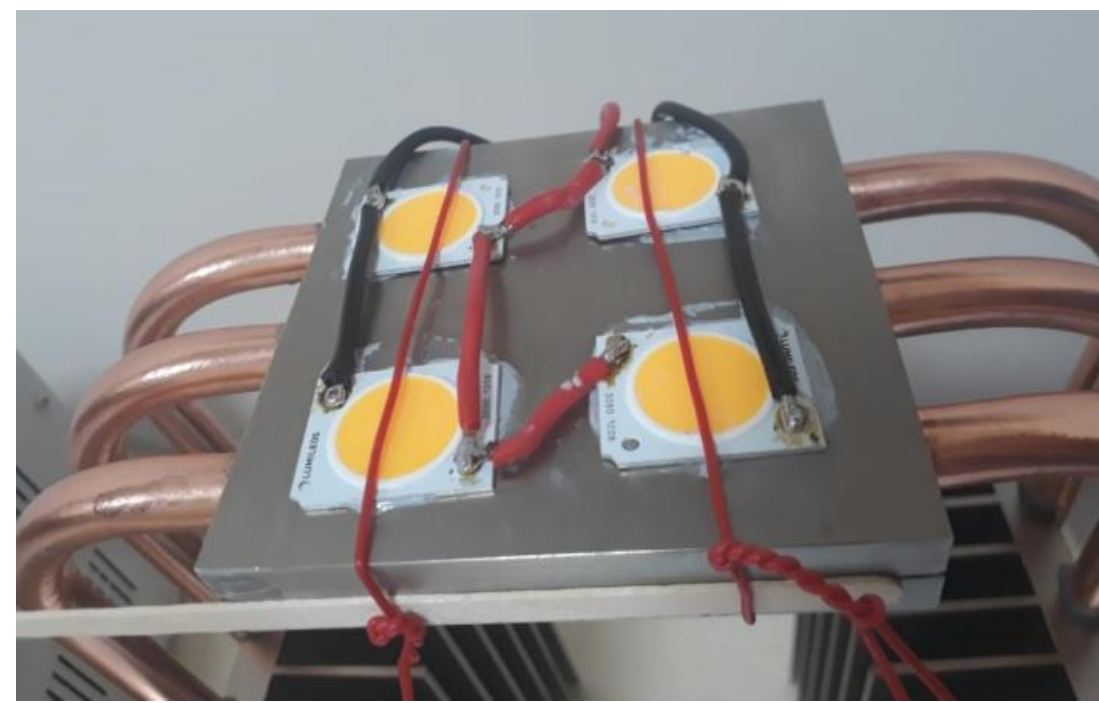

Şekil 3. LED’lerin Elektriksel Bağlantısı ( Electrical Connection of LEDs)

Tasarımda kullanılan LED'in özellikleri Tablo 3'te verilmiștir. LED yongası ve baskılı devre kartından (PCB) oluşan LED ile soğutucu plaka arasında termal ara yüzey malzemesi bulunmaktadır. Elektriksel bağlantısı yapılan LED'lerin çalıştırılması için, 60 volt gerilim ve 5 amper akıma kadar güç sağlayan TT-T-ECNİ-C RXN 605D model ayarlanabilir güç kaynağı kullanılmıştır.

Tablo 3. LED ve Soğutucu Plakanın Boyutları ve Termal İletkenlikleri (Dimensions and Thermal Conductivities of LEDs and

\begin{tabular}{|c|c|c|c|c|}
\hline & Genişlik (mm) & Boyut (mm) & Malzeme & $\begin{array}{c}\text { Termal İletkenlik } \\
\text { (W/m.K) }\end{array}$ \\
\hline LED Yongası & 0.5 & $\mathrm{R}=17.5$ & GaN & 130 \\
\hline $\begin{array}{c}\text { Elektronik Devre } \\
\text { Kartı }\end{array}$ & 1 & $20 \times 24$ & PCB & 8 \\
\hline TIM & 0.05 & $n$ & $\begin{array}{c}\text { Termal ara yüzey } \\
\text { malzemesi }\end{array}$ \\
\hline Soğutucu Plaka & 15 & $80 \times 80$ & Alüminyum 6061 & 202 \\
\hline
\end{tabular}

Lumileds Luxeon 1208 COB LED'lerin veri föyündeki (URL-1) gerilim ve akım diyagramından faydalanılarak, her bir LED'te 25 W' lık güç elde etmek için, yaklaşık 0.720 mA akım ve 34.5 V'luk bir gerilim uygulanmıştır. LED'ler paralel bağlı olduğu için, güç kaynağından çıkacak akım değeri, LED’lere uygulanacak akım değerlerinin toplamına eşit olacaktır. Bu nedenle, dört eş LED için toplam akım değeri $0.720 \times 4=2.880$ Amper olarak belirlenmiştir. Paralel bağlı dirençlerde gerilim değerleri eşit olduğundan, gerilim değeri $34.5 \mathrm{~V}$ olarak ayarlanmıştır.

Elektronik soğutmada, içinde ısı üretimi olan elektronik bileşen ile soğutucu plaka arasında bulunan hava boşlukları, elektronik bileşenden soğutucu plakaya ısı geçişini olumsuz etkiler. LED ile soğutucu plaka arasındaki ara yüzeyin oluşturduğu ilave termal direnci azaltmak için, termal ara yüzey malzemesi kullanılır. Termal ara yüzey malzemeleri, termal olarak iletken olan polimer veya silikon matris parçacıklardan oluşur (Gwinn ve Webb, 2003). Orta derecede bir iletkenlik sağlayabilmek için gerekli termal ara yüzey malzeme kalınlığı, kullanım yerine göre, 2 ile $25 \mathrm{~nm}$ arasında değişir (Schelling, 2005).

Deneysel çalışmada, soğutucu plaka üzerine LED'ler monte edilirken, $8 \mathrm{~W} / \mathrm{m} . \mathrm{K}^{\prime}$ lik ısıl iletkenliğe sahip termal macun kullanılmıştır. Termal macunun her bir LED'in yüzeyine ince bir tabaka halinde homojen olarak sürülmesine dikkat edilmiştir. Sistemi çalıştırırken, olası bir akım artışının LED'lere olumsuz etki etmemesi için, elektriksel devreye 3 amperlik bir bıçak sigorta ve bir açma-kapama düğmesi (olası bir tehlike durumda erken müdahale edebilmek için) yerleştirilmiştir. 
Sıcaklık ölçümleri için 4 adet K tipi termokupl kullanılmıştır. Sıcaklık ölçüm değerlerini belirli zaman aralıklarıyla kaydetmek için, termokupllar, Extech SDL200 marka veri toplayıcısına bağlanmıştır. LED'lere güç verildikten sistemin isıl dengeye gelmesi beklenmiştir. Şekil 4'de gösterilen noktalara monte edilen termokupllar sayesinde sıcaklık değerleri ölçülmüştür. Ölçümler yapılırken ortam sıcaklığı $24.7 \pm 0.3^{\circ} \mathrm{C}$ (termometre ölçümü) ve hava hızı $0.1 \mathrm{~m} / \mathrm{s}$ (anemometre ölçümü) olarak belirlenmiştir. Şekil 5 'te deney düzeneğinin fotoğrafı verilmiștir.

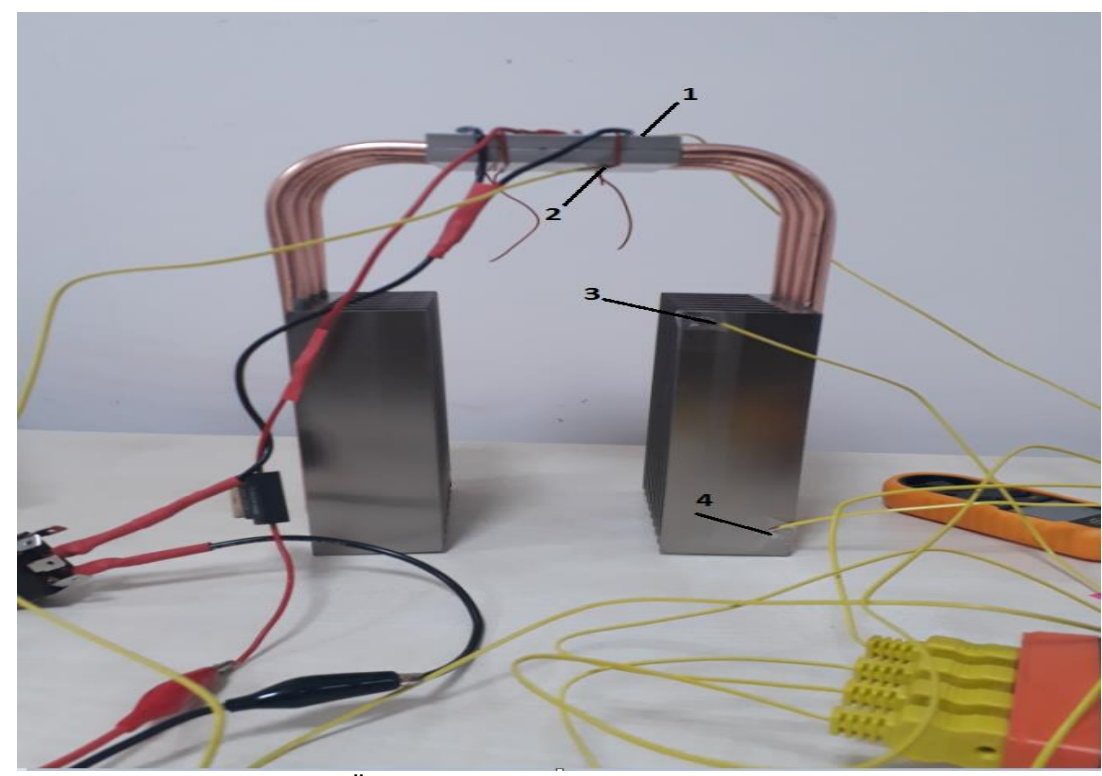

Şekil 4. Termokupl Ölçüm Noktaları (Thermocouple Measuring Points)

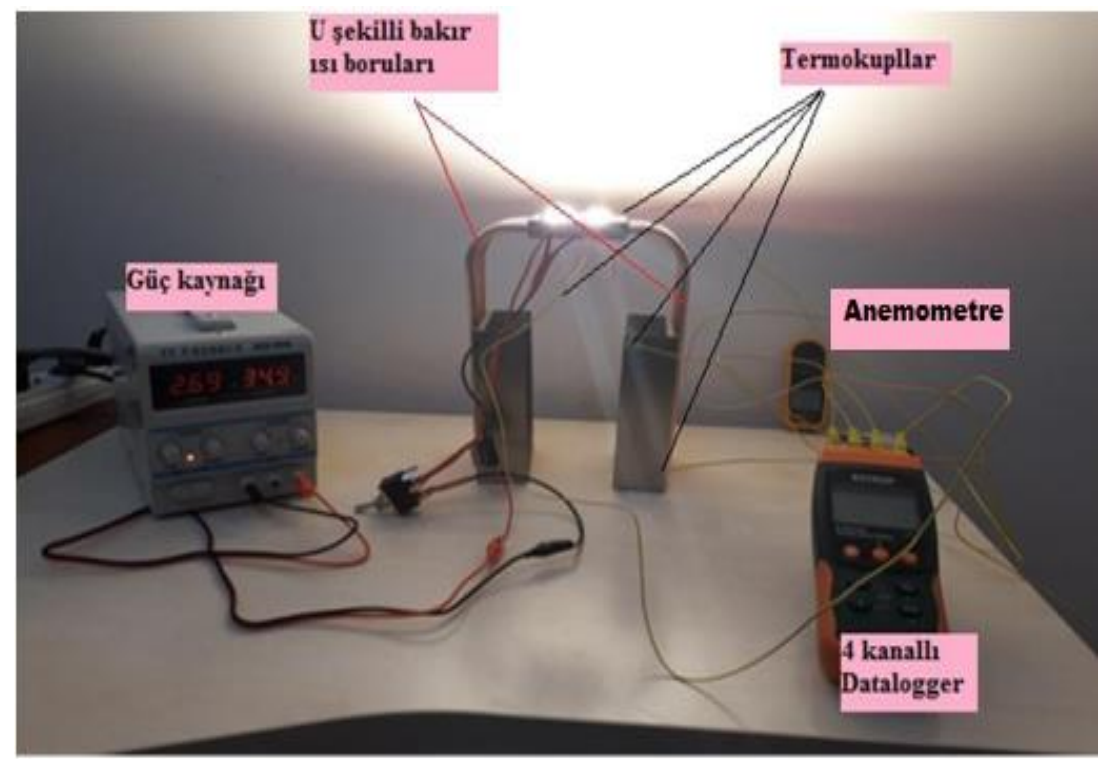

Şekil 5. Deney Düzeneğinin Görüntüsü (View of Experimental Set Up)

\section{Araştırma Bulguları (Research Findings)}

\subsection{Sayısal Modelleme Sonuçları (Numarical Modeling Results)}

ANSYS Fluent yazılımında, verilen sınır koşulları altında, modelin termal analizi farklı güç girişleri için gerçekleștirilmiştir. Yaklaşık 4500 iterasyon sonucunda modelin yakınsadığı görülmüştür. Şekil 6, Şekil 7 ve Şekil 8'de sırasıyla $15 \mathrm{~W}, 20 \mathrm{~W}$ ve $25 \mathrm{~W}$ 'lık güç girişleri için elde edilen sıcaklık dağılımları verilmiştir. Buna göre, 25 W'lık güç girişi için $78.6^{\circ} \mathrm{C}, 20 \mathrm{~W}$ 'lık güç girişi için $71.2^{\circ} \mathrm{C}$ ve $15 \mathrm{~W}^{\prime} \mathrm{l}$ lk güç girişi için $64.2^{\circ} \mathrm{C}$ maksimum sıcaklık değerleri elde edilmiştir. LED'lere uygulanan güç girişi azaldıkça, sistemin maksimum sıcaklığında düşüş gözlenmiştir. 


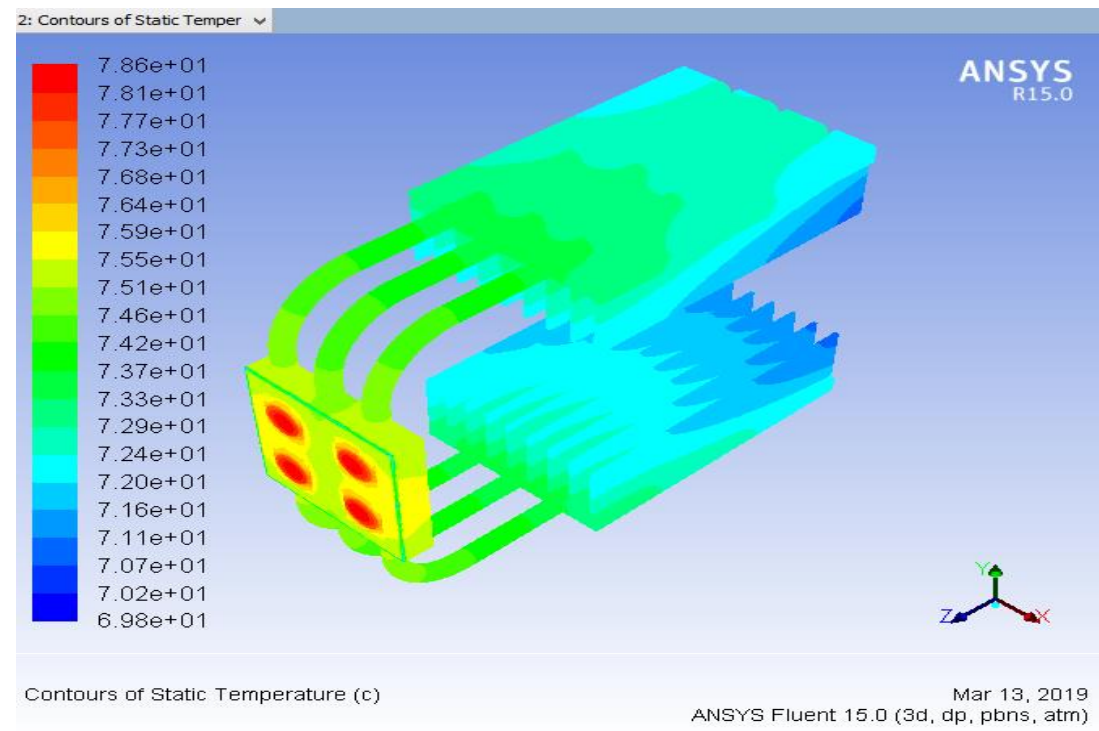

Şekil 6. 25 W'lık elektriksel giriş gücü için tasarlanan sistemin verilen geometri ve sınır şartlarında sıcaklık dağılımı (Temperature Distribution of The Designed System in Given Geometry and Boundary Conditions for 25 W Electrical Input Power)

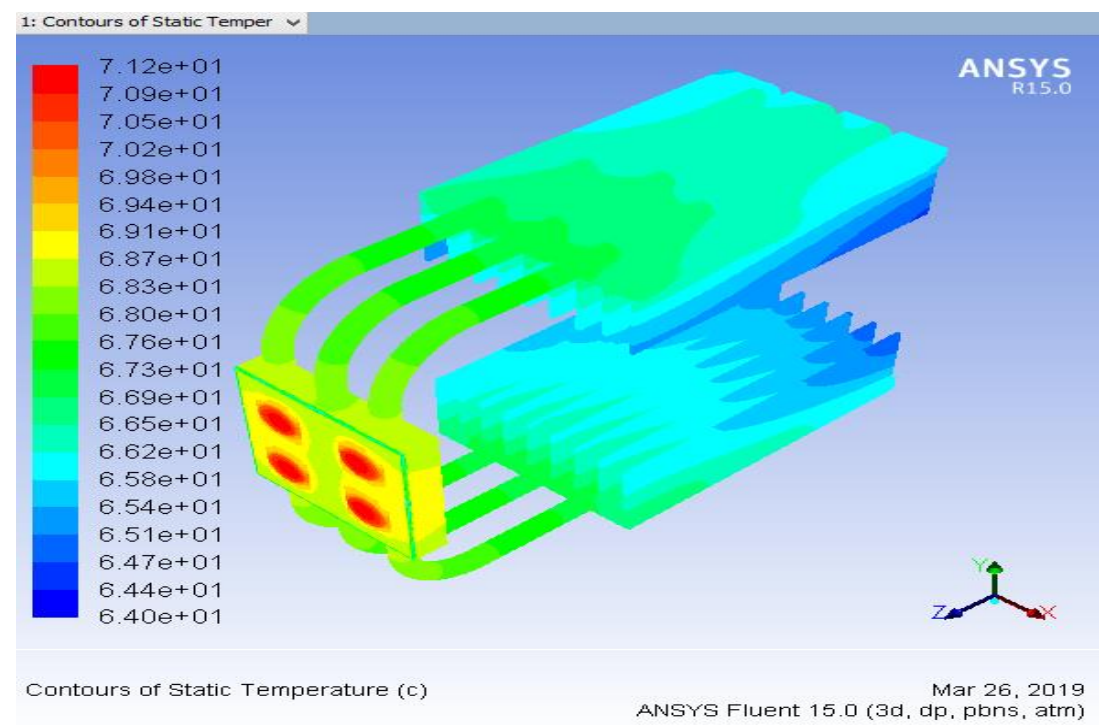

Şekil 7. 20 W'lık elektriksel giriş gücü için tasarlanan sistemin verilen geometri ve sınır şartlarında sıcaklık dağılımı (Temperature Distribution of The Designed System in Given Geometry and Boundary Conditions for 20 W Electrical Input Power)

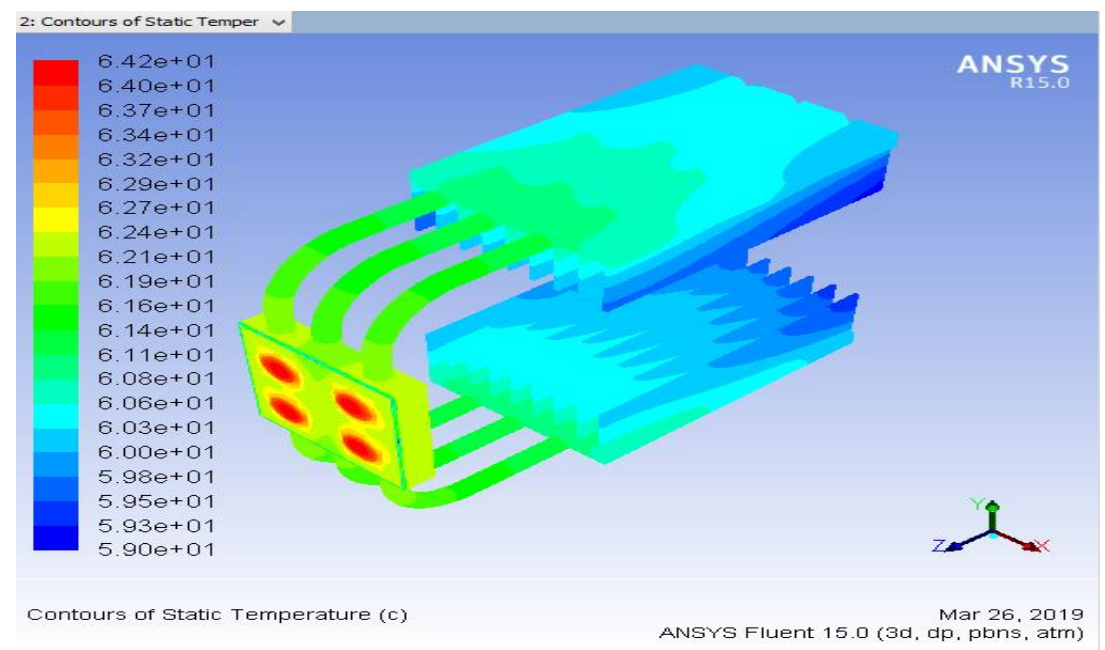

Şekil 8. 15 W'lık elektriksel giriş gücü için tasarlanan sistemin verilen geometri ve sınır şartlarında sıcaklık dağılımı (Temperature Distribution of The Designed System in Given Geometry and Boundary Conditions for 25 W Electrical Input Power) 
Şekil 9'da termal direnç ağ modeli verilen sistemde, maksimum LED sıcaklığı, $\mathrm{T}_{\mathrm{b}}$, evaporatör bölgesi sıcaklığl, Te, kondenser bölgesinin ortalama sıcaklığl, $\mathrm{T}_{\mathrm{c}}$ ve ortam sıcaklığı, $\mathrm{T}_{\mathrm{a}}$ olarak ifade edilmiştir. Sistemin toplam termal direnci hesaplanırken sistem iki alt sisteme ayrılmış ve LED'den soğutucu plakaya kadar olan kısmın toplam termal direnci $\mathrm{R}_{\text {th1 }}$ olarak, ısı borusu ve kanatçıkları kapsayan diğer kısmın toplam termal direnci ise $\mathrm{R}_{\text {th2 }}$ olarak tanımlanmıştır. Sistemin toplam termal direnci Eşitlik (6)'daki gibi hesaplanır.

$$
\begin{gathered}
\mathrm{R}_{\mathrm{th}}=\mathrm{R}_{\mathrm{th} 1}+\mathrm{R}_{\mathrm{th} 2} \\
\mathrm{R}_{\mathrm{th} 1}=\left(\sum_{\mathrm{i}=1}^{4} \frac{1}{\mathrm{R}_{\mathrm{LEDi}}}\right)^{-1} \\
\mathrm{R}_{\mathrm{th} 2}=\left(\sum_{\mathrm{i}=1}^{6} \frac{1}{\mathrm{R}_{\mathrm{h}, \mathrm{i}}+\mathrm{R}_{\mathrm{f}, \mathrm{i}}}\right)^{-1}
\end{gathered}
$$

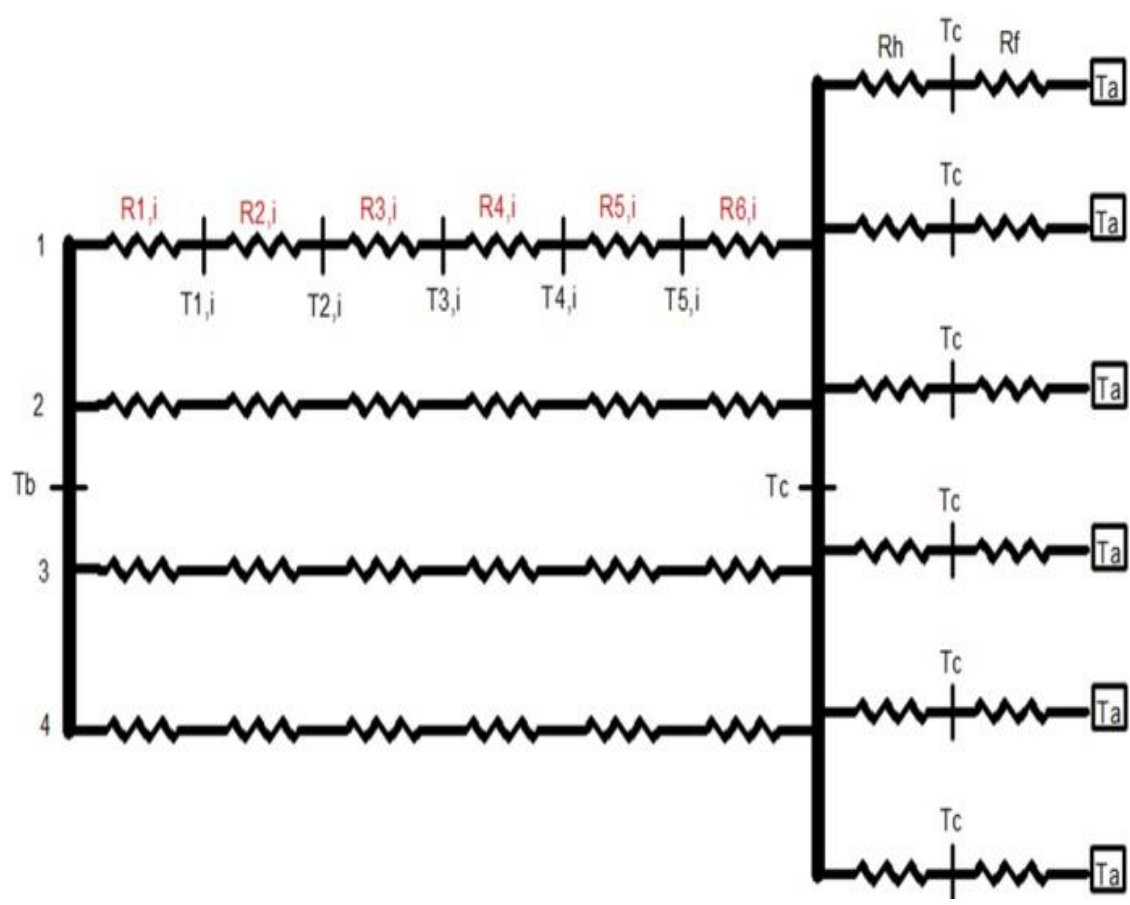

Şekil 9. Tasarlanan Sistemin Termal Direnç Ağ Șeması (Thermal Resistance Network of The Designed System)

LED'lerde jonksiyon sıcaklığı oldukça önemli bir parametredir çünkü LED ömrü ve ışık akısı gibi parametreler büyük ölçüde jonksiyon sıcaklığına bağlıdır. LED jonksiyon sıcaklığı, Eşitlik (9)'daki gibi hesaplanır. Eşitlikte verilen $I_{F}$, ileri yönde akımı, $V_{F}$ ise ileri yönde gerilimi ifade eder. Jonksiyon sıcaklığını hesaplamak için, sistemin toplam termal direnci bilinmelidir.

$$
T_{j}=T_{a}+R_{t h} \times I_{F} \times V_{F}
$$

ANSYS Fluent yazılımında yapılan analizler sonunda, sistemin belirli noktalardan sıcaklık değerleri alınmıştır. Her bir güç girişi için hesaplanan toplam termal direnç ve jonksiyon sıcaklık değerleri Tablo 4'te verilmiştir.

Tablo 4. Farklı Elektriksel Güç Girişleri için Toplam Termal Direnç ve Jonksiyon Sıcaklık Değerleri (Values of Total Thermal

Resistance and Junction Temperature for Different Electrical Power Inputs
\begin{tabular}{|l|l|l|}
\hline $\begin{array}{l}\text { Elektriksel Güç } \\
\text { Girişi (W) }\end{array}$ & $\begin{array}{l}\text { Toplam Termal } \\
\text { Direnç }\left({ }^{\circ} \mathbf{C} / \mathbf{W}\right)\end{array}$ & $\begin{array}{l}\text { Jonksiyon } \\
\text { Sicaklığ } \mathbf{~}\left({ }^{\circ} \mathbf{C}\right)\end{array}$ \\
\hline 25 & 0.546 & 89.6 \\
\hline 20 & 0.566 & 80.3 \\
\hline 15 & 0.608 & 71.5 \\
\hline
\end{tabular}

Literatürde U-tipi silindirik ısı borusunun elektronik soğutmada kullanılmasıyla ilgili çalışmalar mevcuttur. Elnaggar vd. (2011)’ın 24 W güç girişi için üç adet U-tipi silindirik ısı borusu kullandığı çalışmada toplam termal direnç değeri $0.441^{\circ} \mathrm{C} / \mathrm{W}$ olarak bulunmuştur. Chang-Wang (2014), yaptığı çalışmada iki adet U-tipi silindirik ısı 
borusu zorlanmış taşınım (fanlı soğutma) koşullarında kullanmıştır. $15 \times 15$ mm²'lik ısı kaynağına girilen $60 \mathrm{~W}$, $80 \mathrm{~W}$ ve $100 \mathrm{~W}^{\prime}$ lık güç girişleri için toplam termal direnç değerleri sırasıyla $0.63^{\circ} \mathrm{C} / \mathrm{W}, 0.62{ }^{\circ} \mathrm{C} / \mathrm{W}$ ve $0.615^{\circ} \mathrm{C} / \mathrm{W}$ olarak verilmiştir. Buna göre ıSı kaynağına verilen güç arttıkça toplam termal direnç değerinin azaldığı gözlenmiștir. Bu çalışmada bulunan sonuçlar da aynı durumu işaret etmektedir. Mevcut çalışmada fan kullanmadan, doğal taşınım koşullarında, kabul edilebilir termal direnç değerlerinin elde edildiği görülmüştür.

\subsection{Farklı Türbülans Modelleri ve Duvar Yaklaşımlarının Maksimum Sıcaklığa Etkisi (Effect of Different Turbulence Models and Wall Approacheson Maximum Temperature)}

Duvar fonksiyonları, hesaplamalı akışkanlar dinamiğinde yaygın olarak kullanılır ve hesaplamalarda oldukça kolaylık sağlar. Tasarlanan sistemin termal analizlerinde, türbülans modeli olarak Turbulent Mixing Lengh modeli kullanılmıştır. Çalışmada ek olarak başlangıç ve sınır değerleri değiştirilmeden, Standart $k-\varepsilon, R n g-k-\varepsilon$, Realizable $k-\varepsilon$, Standart $k-w$ ve SST-k-w gibi türbülans modelleri, Standart Wall Function, Enhanced Wall Treatment ve Non Equilibrium Wall Function gibi farklı duvar yaklaşımlarıyla birlikte uygulanmış ve maksimum LED sıcaklık değerleri elde edilmiştir. Farklı türbülans modeli ve duvar yaklaşımları ile yapılan analizler sonucunda elde edilen sıcaklık değerleri Tablo 5 'de verilmiştir.

Tablo 5. Türbülans Modeli ve Duvar Yaklaşımlarına Göre Maksimum LED Sıcaklık Değerleri (Maximum LED Temperature Values for Turbulence Model and Wall Approaches)

\begin{tabular}{|c|c|c|}
\hline $\begin{array}{l}\text { Türbülans } \\
\text { Modeli }\end{array}$ & Duvar Yaklaşımı & $\begin{array}{l}\text { Maksimum LED Sıcaklığı } \\
\left({ }^{\circ} \mathrm{C}\right)\end{array}$ \\
\hline $\begin{array}{l}\text { Turbulent Mixing } \\
\text { Length }\end{array}$ & - & 78.6 \\
\hline \multirow{3}{*}{ Standart k- $\varepsilon$} & Standard Wall Function & 81.5 \\
\hline & Enhanced Wall Treatment & 83.8 \\
\hline & Non Equilibrium Wall Function & 75.5 \\
\hline \multirow{3}{*}{ Rng-k- $\varepsilon$} & Standard Wall Function & 83.7 \\
\hline & Enhanced Wall Treatment & 84.4 \\
\hline & Non Equilibrium Wall Function & 84.5 \\
\hline \multirow{3}{*}{$\begin{array}{l}\text { Realizable } \\
\quad \mathbf{k - \varepsilon}\end{array}$} & Standard Wall Function & 84.0 \\
\hline & Enhanced Wall Treatment & 83.9 \\
\hline & Non Equilibrium Wall Function & 76.8 \\
\hline Standart k-w & - & 83.8 \\
\hline SST-k-w & - & 84.7 \\
\hline
\end{tabular}

\subsection{Deneysel Çalışma Sonuçları (Experimental Results)}

Sistem sıcaklık verileri, SDL 200 EXTECH marka veri toplayıcısına bağlanan 4 adet K-tipi termokupl tarafindan alınmıştır. Bu 4 termokupl, sistemde Şekil 4'de belirtilen noktalara monte edilmiştir. Sistemin sıcaklık ölçümleri 60 dakika boyunca devam etmiş ve 30 saniye aralıklarla kaydedilmiştir. Kayıt işlemi bittikten sonra, veri toplayıcısı SD kartını bilgisayara bağlayarak veriler Excel programına aktarılmıştır. Daha sonra, bu veriler kullanılarak, her bir güç girişi için Şekil 10-12'de verilen sıcaklık-zaman grafikleri oluşturulmuştur. Buna göre $\mathrm{T}_{1}$, LED maksimum sıcaklığı, $\mathrm{T}_{2}$, içinde ısı borusu evaporatör kısmı bulunan soğutucu plakanın alt bölge sıcaklığı, $T_{3}$ ve $T_{4}$, kanatçıklı alüminyum plakanın üst ve alt bölgelerinin sıcaklık değerleridir. T 1 noktasının sıcaklığı ilk olarak hızlı bir artıș gösterip daha sonra ısının, sistemin alt kısımlarına doğru aktarılması ile bir miktar azalmaktadır. $\mathrm{T}_{2}, \mathrm{~T}_{3}$ ve $\mathrm{T}_{4}$ noktası sıcaklıkları, sistem çalıştıktan sonra LED'den kanatçıklara doğru ısı aktarımı gerçekleştikçe artmakta ve zamanla stabil hale gelmektedir. 


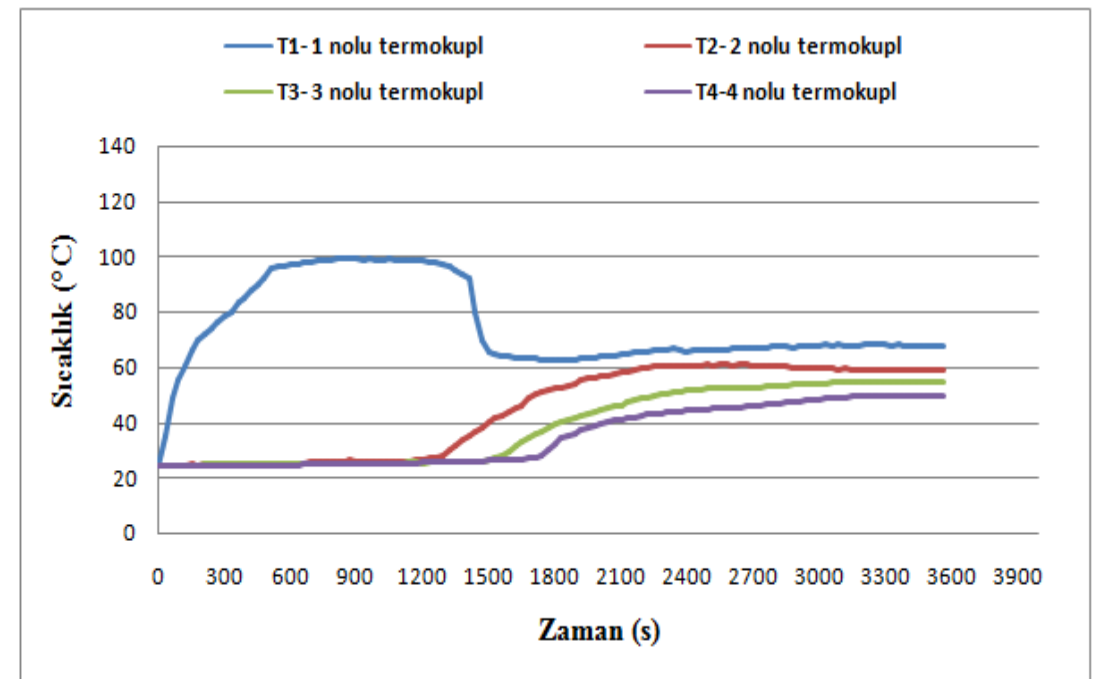

Şekil 10. 15 W'lık Elektriksel Güç Giriși İçin Sistemde Belirlenen Noktaların Zamana Göre Sıcaklık Dağılımı (Temperature Distributions of Specified Points with Respect to Time, 15 W Electrical Power Input)

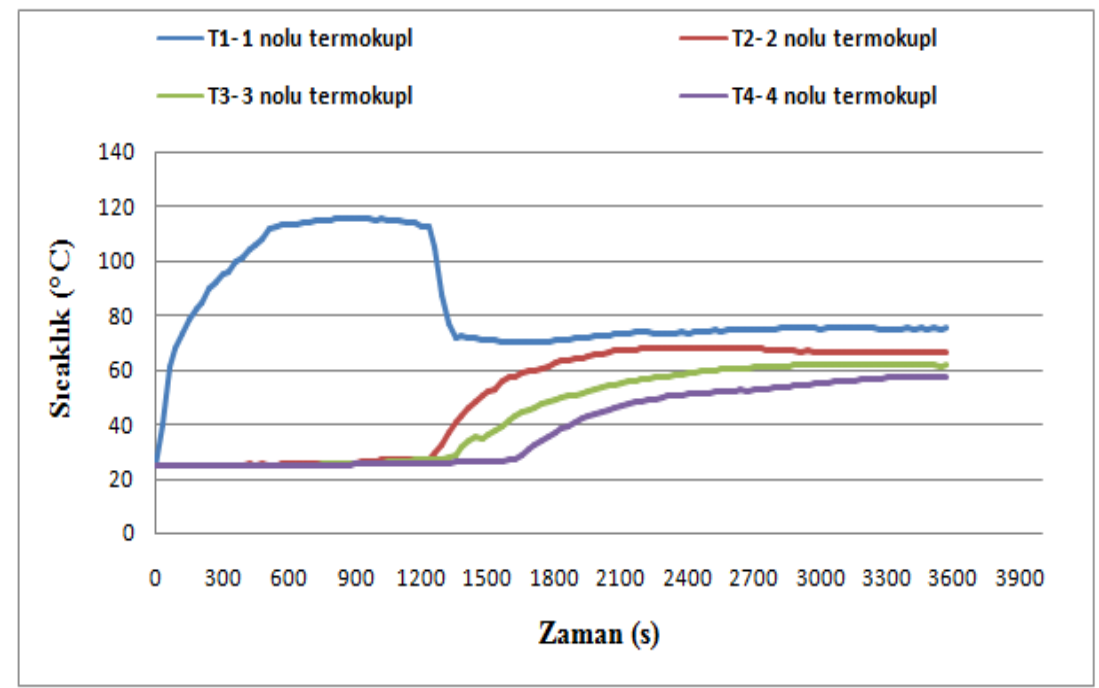

Şekil 11. 20 W'lık Elektriksel Güç Girişi İçin Sistemde Belirlenen Noktaların Zamana Göre Sıcaklık Dağılımı (Temperature Distributions of Specified Points with Respect to Time, 20 W Electrical Power Input)

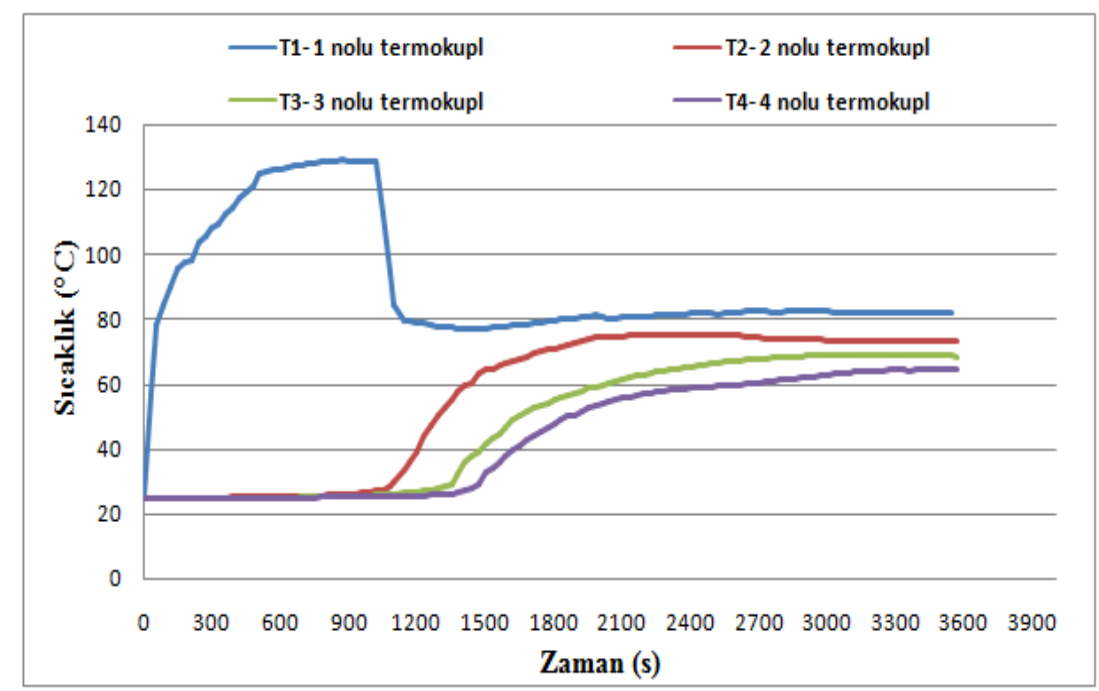

Şekil 12. 25 W'lık Elektriksel Güç Girişi İçin Sistemde Belirlenen Noktaların Zamana Göre Sıcaklık Dağılımı (Temperature Distributions of Specified Points with Respect to Time, 25 W Electrical Power Input)

Sistemin sıcaklık ölçümlerini doğrulamak için termal kamera kullanılmıştır. Ölçümler, $160 \times 120$ piksel çözünürlüğe sahip Optris PI termal kamera ile yapılmıştır. Sistem kararlı hale geldikten sonra, LED'lerin 
maksimum sıcaklık değerleri termal kamera ile ölçülmüştür. Termal kamera ile termokupllardan alınan değerlerin birbirine yakın olduğu görülmüştür. Şekil 13'de, 25 W'lı güç girişi için termal kamera ile ölçülen LED sıcaklık değeri verilmiştir.

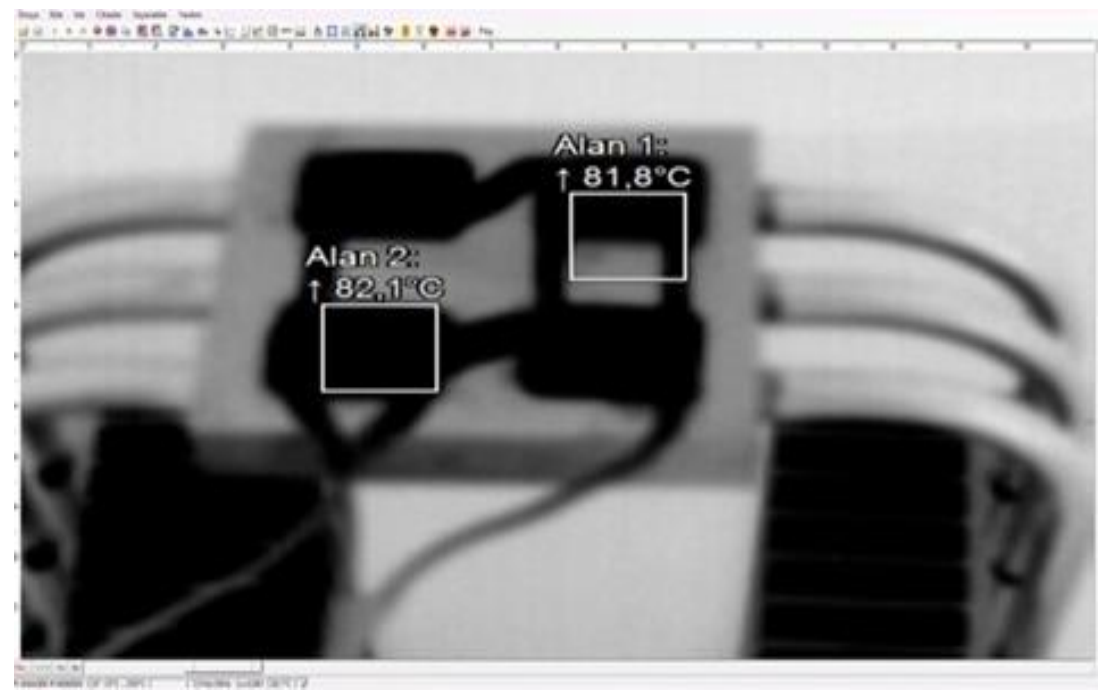

Şekil 13. 25 W'lık Elektriksel Güç Girişi için Sistemin Termal Kamera ile Sıcaklık Ölçümü (Temperature Measurement of the LEDs with Thermal Camera for 25 W Electrical Power Input)

\subsection{Deneysel Belirsizlik (Experimental Uncertainty Analysis)}

Deneysel belirsizlik, temel olarak sıcaklık ölçüm sürecinin rassal hatası olarak tanımlanır. Belirsizliklerin, elektriksel güç girişi ve sıcaklık ölçümlerindeki değişimlerden ve kalibrasyonlardaki hatalardan kaynaklandığı düşünülmektedir. Termokuplların ölçüm hassasiyeti $\pm 0.1{ }^{\circ} \mathrm{C}$ dir. $\mathrm{Bu}$ nedenle, sıcaklık ölçümünün mutlak belirsizliği dT, $0.1^{\circ} \mathrm{C}$ olarak alınmıştır. DC güç kaynağında okunan gerilim değerinin verdiği hata (dU), \pm 0.5 Volt, akım değerinin verdiği hata (dI), \pm 0.5 Amper ve SD kart çözünürlüğ̈̈nün verdiği hata $\left(\mathrm{dT}_{\text {data }}\right), \pm 0.1^{\circ} \mathrm{C}$ olarak belirlenmiștir. Sıcaklık ölçüm belirsizliği (UT), tüm belirsizlikler göz önünde bulundurularak, Eșitlik (10)' daki gibi ifade edilir (Kline, 1985). Burada Tave, her sıcaklık ölçüm noktasının ortalama değerini belirtir. Hesaplamalar sonucu belirsizlik değerinin \% 1.5'dan \% 2.2'ye kadar değiștiği görülmüştür.

$$
\mathrm{U}_{\mathrm{T}}=\sqrt{\left(\frac{\mathrm{dT}}{\text { Tave }}\right)^{2}+\left(\frac{\mathrm{dTdata}}{\text { Tave }}\right)^{2}+\left(\frac{\mathrm{dU}}{\mathrm{U}}\right)^{2}+\left(\frac{\mathrm{dI}}{\mathrm{I}}\right)^{2}}
$$

\section{Sonuç ve Tartışma (Result and Discussion)}

Bu çalışmada, sokak aydınlatmalarında kullanılan yüksek güçlü LED'lerin soğutulması için ısı borulu soğutucu plaka tasarlanmıştır. Isı borulu soğutucu plaka üzerine yüksek güçlü dört eş COB LED'in yerleştirilmesiyle tamamlanan sistemin termal analizi, sayısal olarak ANSYS Fluent yazılımında yapılmıştır. Analizler, 15 W, 20 W ve 25 W'lık elektriksel güç girişleri için başlangıç ve sınır koşulları değiştirilmeden tekrarlanmıştır. Elde edilen sonuçlarla, LED'lere uygulanan farklı güç girişlerinin, LED maksimum sıcaklığına etkisi karşılaştırılmıştır. Buna göre, LED'lere uygulanan $15 \mathrm{~W}, 20 \mathrm{~W}$ ve 25 W'lık güç girişleri için, LED maksimum sıcaklıkları, sırasıyla $64.2^{\circ} \mathrm{C}$, $72.1^{\circ} \mathrm{C}$ ve $78.6^{\circ} \mathrm{C}$ olarak bulunmuştur. Analiz sonuçları, hesaplanan jonksiyon sıcaklıklarının izin verilen değerin altında kaldığını ve tasarlanan sistemin LED'leri soğutmak için yeterli olduğunu göstermiştir. ANSYS Fluent yazılımında analizler yapılırken, Türbülans modeli olarak Turbulent Mixing Length kullanılmıştır. Bu çalışmada ek olarak başlangıç ve sınır şartları değişmeden farklı türbülans modeli ve duvar yaklaşımları kullanılarak LED maksimum sıcaklığına etkisi de incelenmiștir. Analizlerde kullanılan 6 farklı türbülans modeli ve 3 farklı duvar yaklașımı sonucunda LED maksimum sıcaklıklarında gözle görülür farklılıklar olduğu görülmüștür. Aynı türbülans modelinde farklı duvar yaklaşımları kullanıldığında, maksimum LED sıcaklık değerleri arasında yaklaşık $8{ }^{\circ} \mathrm{C}$ ye kadar değişim gözlenmiştir.

Deneysel çalışma, yapılan sayısal analizlerin doğrulanması ve tasarlanan model için en uygun türbülans modeli ve duvar yaklaşımının belirlenebilmesi için yapılmıştır. Sistem kararı hale geldikten sonra ölçümler hem K-tipi termokupllar ile hem termal kamera ile yapılmıştır. Deneysel ölçüm sonuçları ise, aynı güç girişleri için, aynı sırayla, $68^{\circ} \mathrm{C}, 74.4{ }^{\circ} \mathrm{C}$ ve $82.2^{\circ} \mathrm{C}$ olarak ölçülmüştür. Deneysel sonuçlar ile analiz sonuçları arasındaki en büyük hata \%5.92, korelasyon katsayısı ise 0.9992 olarak hesaplanmıștır. Bu durumda, sayısal modelin, tasarlanan 
sistemi yeterli bir doğrulukla simüle ettiği söylenebilir. Deneysel ölçümler sonucunda tasarlanan model için en iyi sonuç, Standart $k-\varepsilon$ türbülans modeli ve Standard Wall Function duvar yaklaşımında elde edilmiştir.

\section{Teșekkür (Acknowledgement)}

Bu çalışma, 15.02.2019 tarihli, 540357 numaralı, "M1 ve M2 kategorisinde tanımlanan yol aydınlatma sınıflarına uygun ve yüksek verimli LED'li yol aydınlatma armatür modellerinin tasarımı ve termal analizi” başlıklı doktora tez çalışmasından derlenmiştir.

\section{Çıkar Çatışması (Conflict of Interest)}

Yazarlar tarafından herhangi bir çıkar çatışması beyan edilmemiştir. No conflict of interest was declared by the authors.

\section{Kaynaklar (References)}

Ashish, R., Chaudhari, Bhosale, S.Y., 2016. CFD Validation and Experimental Investigation of Circular Heat Pipe Using Hybrid Nanofluid,International Journal of Innovative Research in Science, Engineering and Technology, 5, 9, 16058-16064.

Asmaie, L., Haghshenasfard, M., Mehrabani-Zeinabad, A., Esfahany, M.N., 2013. Thermal Performance Analysis of Nanofluids in a Thermosyphon Heat Pipe Using Cfd Modeling, Heat and Mass Transfer, 49, 5, 667-678.

Cai, Y., Li, Z., Zhai, J., Tang, Y., Yu, B., 2017. Experimental İnvestigation On a Novel Multi-Branch Heat Pipe for Multi-Heat Source Electronics, International Journal of Heat and Mass Transfer, 104, 467-477.

Dev, K., Budania, B., 2016. Simulation and Modeling Of Heat Pipe, International Journal of Technical Research, 5,1.

Elnaggar, M. H., Abdullah, M. Z., Mujeebu, M. A. 2011. Experimental analysis and FEM simulation of finned U-shape multi heat pipe for desktop PC cooling, Energy Conversion and Management, 52(8-9), 2937,2944.

Elnaggar, M., 2013. The Effect Of Thickness and Permeability of Wick Structure on L-Shape Heat Pipe Performance Using Different Working Fluids, Frontiers in Heat Pipes (FHP), 3, 4.

Gwinn, J.P., Webb, R.L., 2003. Performance and Testing of Thermal Interface Materials, Microelectron Journal, 34, $215-22$.

Huang, D. S., Chen, T. C., Tsai, L. T., Lin, M. T., 2019. Design of Fins with a Grooved Heat Pipe for Dissipation of Heat From HighPowered Automotive LED Headlights, Energy Conversion and Management, 180, 550-558.

Kline, S.J., 1985. The Purposes Of Uncertainty Analysis, Journal of Fluids Engineerings, 107, 2, 153-160.

Lin, Z., Wang, S., Shirakashi, R., Zhang, L.W., 2013. Simulation of a Miniature Oscillating Heat Pipe in Bottom Heating Mode Using Cfd with Unsteady Modeling, International Journal of Heat and Mass Transfer, 57, 2, 642-656.

Moon, S. H., Park, Y. W.,Yang, H. M.,2016. A Single Unit Cooling Fins Aluminum Flat Heat Pipe for 100 W Socket Type COB LED Lamp, Applied Thermal Engineering, 126, 1164-1169.

Naveenkumar, C., Kumar, P.V., Kumar, K.D., 2015. Simulation and CFD Analysis of Heat Pipe With Different Wick Geometry Using CFX, International Journal of Thermal Technologies, 5, 3, 210-213.

Pimputkar, S.,Speck, J.S., Denbaars, S.P., Nakamura, S., 2009. Prospects for Led Lighting, Nat. Photonics,2,180-182.

Schelling, P.K., Shi, L., Goodson, K. E.,2005. Managing Heat for Electronics, Materials Today, 8, 6, 30-35.

Schmid, G., Huang, Z.L., Yang, T.H., Chen, S.L., 2017. Numerical Analysis of a Vertical Double-Pipe Single-Flow Heat Exchanger Applied in an Active Cooling System for High-Power Led Street Lights, Applied Energy, 195, 426-438.

Suresh, Z.V., Bhramara, B., 2016. Cfd Analysis of Single Turn Pulsating Heat Pipe, International Journal Of Scientific And Engineering Research, 7, 6, 238-244.

Tang, Y., Ding, X., Li, Z., Li, B., 2014. A High Power Led Device with Chips Directly Mounted on Heat Pipes, Applied Thermal Engineering, 66, 632-639.

Wang, J. C., 2014. U-and L-shaped heat pipes heat sinks for cooling electronic components employed a least square smoothing method, Microelectronics Reliability, 54(6-7), 1344,1354.

Wang, M., Tao, H., Sun, Z., Zhang, C., 2017. The Development and Performance of the High Power Led Radiator, International Journal Of Thermal Sciences, 113, 65-72.

URL-1< https://www.lumileds.com/uploads/419/ DS115-pdf/>: (Erişim tarihi: 12.02.2019). 